\title{
ANALISIS TINGKAT PENGETAHUAN MASYARAKAT TERHADAP ZAKAT PERKEBUNAN KELAPA SAWIT DI DESA TELUK MERBAU KECAMATAN DAYUN KABUPATEN SIAK
}

\author{
Daharmi Astuti ${ }^{1}$ \& Rezeki Arnanda ${ }^{2}$ \\ ${ }^{1 \& 2}$ Fakultas Agama Islam, Universitas Islam Riau \\ Email:daharmi_astuti@fis.uir.ac.id,rizkyarnanda21@gmail.com
}

\begin{abstract}
ABSTRAK
Penelitian ini dilatar belakangi adanya beberapa persoalan pertama, masih terbatasnya pengetahuan masyarakat terhadap zakat kadar atau nishab zakat perkebunan. Kedua, kurangnya kesadaran masyarakat dalam membayar zakat perkebunan. Ketiga, rendahnya jumlah pengumpulan zakat dari potensi zakat yang seharusnya terkumpul, khususnya dari aspek zakat perkebunan kelapa sawit. Rumusan penelitian ini adalah bagaimana tingkat pengetahuan masyarakat terhadap zakat perkebunan kelapa sawit. Tujuan penelitian ini adalah untuk mengetahui sampai sejauh mana pengetahuan masyarakat terhadap zakat perkebunan kelapa sawit. Subjek penelitian ini adalah Masyarakat Desa Teluk Merba. Sedangkan objek penelitian ini adalah tingkat pengetahuan masyarakat Desa Teluk Merbau terhadap zakat perkebunan kelapa sawit. Sumber data yang digunakan adalah sumber data primer dan sekunder. Teknik pengambilan sampel adalah menggunakan rumus Slovin, sedangkan teknik pengumpulan data ialah menggunakan angket. Analisis data menggunakan metode kuantitatif dan analisis deskriptif dimana proses perhitungan menggunakan SPSS For Windows versi 23.0. dengan sampel penelitian sebanyak 84 orang. Berdasarkan hasil penelitian tentang analisis tingkat pengetahuan masyarakat Desa Teluk Merbau terhadap zakat perkebunan kelapa sawit yang diperoleh dari jawaban responden dapat disimpulkan $\mathrm{P}=66,80 \%$ yang berarti analisis tingkat pengetahuan masyarakat Desa Teluk Merbau terhadap zakat perkebunan kelapa sawit tergolong "kuat atau mengetahui" dengan persentase 61\%-80\%.
\end{abstract}

Kata Kunci : Pengetahuan, Masyarakat, Desa Teluk Merbau, Zakat Perkebunan Kelapa Sawit.

\begin{abstract}
This study is motivated by the several problems, namely: First, the low amount of zakat collection from the potential zakat that should have been collected. Second, the lack of public awareness in paying plantation zakat. Third, the people still have limited knowledge about zakat amount or nishab on oil palm plantation. The formulation of this research is: how is the level of people's knowledge about the zakat on oil palm plantation?. The aim of this study is to investigate people's knowledge about the zakat on oil palm plantation. The subjects of this research: the people in Teluk Merba Village. While the object of this study is the level of people's knowledge in Teluk Merbau Village about the zakat on oil palm plantation. The data sources used in this study are primary and secondary data. The sampling technique used is the Slovin formula, while the data collection technique used is a questionnaire. Data analysis using quantitative methods and descriptive analysis is used with the calculation process performed by SPSS For Windows version 23.0. The sample of this study consists of 84 people. Based on the results of the study on the analysis of the level of people's knowledge in Teluk Merbau Village on the zakat of oil palm plantation obtained from the respondents' answers, it can be concluded that $P=66.80 \%$, it means that the analysis of the level of people's knowledge in Teluk Merbau Village about the zakat on oil palm plantation is classified as "strong or knowing well" with the percentage of $61 \%-80 \%$.
\end{abstract}

Keywords : Knowledge Level, Community, Teluk Merbau Village, Zakat on Oil Palm Plantation. 


\section{PENDAHULUAN}

Islam merupakan agama terakhir yang diturunkan oleh Allah SWT kepada umat manusia melalui Nabi terakhir yaitu Muhammad SAW. Sebagai Agama terakhir, Islam memiliki berbagai aturan dan tata laksana yang harus di lalukan oleh umatnya, baik yang sifatnya "melanjutkan" ajaran sebelumnya ataupun "membuat" ajaran yang baru. Salah satu ajaran Islam yang sifatnya "melanjutkan" tersebut adalah ibadah zakat.

Zakat merupakan rukun Islam yang ketiga dan menjadi salah satu pilar tegaknya agama Islam. Perintah pemberian zakat telah diterangkan secara jelas dalam Al-Qur'an :

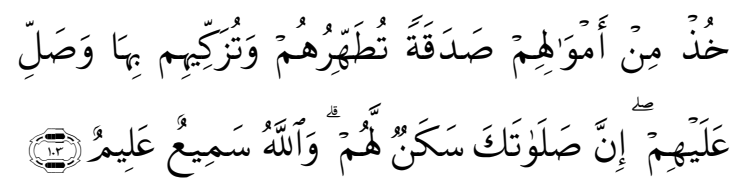

Artinya: "Ambillah zakat dari harta mereka guna membersihkan dan mensucikan mereka dan berdo'alah untuk mereka. Sesungguhnya do'amu itu (menumbuhkan) ketentraman jiwa bagi mereka. Allah Maha Mendengar, Maha Mengetahui." (Q.S. At-Taubah ayat 103)

Secara umum zakat didefinisikan sebagai bagian tertentu dari harta kekayaan yang diwajibkan Allah SWT untuk sejumlah orang yang menerimanya. Mahmud Syaltut, seorang ulama kotemporer dari Mesir, mendefinisikan sebagai ibadah kebendaan yang diwajibkan oleh Allah SWT agar orang kaya menolong yang miskin berupa kebutuhan pokok untuk memenuhi kehidupannya sehari-hari. (Astuti et al, 2017)

Pengertian zakat secara garis besar adalah kadar harta yang tertentu, yang wajib dikeluarkan oleh seseorang apabila telah memenuhi syarat-syarat yang telah ditentukan oleh agama Islam dan didistribusikan kepada orang yang berhak menerima zakat tersebut. (H. Rasjid, 2014).

Aspek pengelolaan zakat atau adminitrasi zakat tidak banyak mendapat pengaturan dalam syariat Islam. Nabi Muhammad SAW tercatat mengelola dan meregulasi zakat secara langsung dan memperlakukannya sebagian bagian dari keuangan negara. Namun contoh itu terjadi dalam kondisi struktur negara yang masih sederhana, tingkat perekonomian yang rendah dan luas wilayah kekuasaan negara yang terbatas. Maka sejarah Islam mencatat, seiring perluasan wilayah kekuasaan. Tingkat perekonomian yang semakin menjauh, dan struktur pemerintahan yang semakin kompleks, kebijakan terkait pengelolaan zakat berubah secara dinamis sesuai perubahan zaman, yang terlihat mengikuti kebijakan pemerintah terkait rakyat terkait dengan kemanfaatan.

Perkembangan zakat di Indonesia meningkat secara signifikan pada saat pemerintah mengesahkan UU No. 38 Tahun 1999. Yang menyatakan bahwa, zakat dapat dikelola oleh lembaga zakat yang dibentuk pemerintah (Badan Amil Zakat), maupun lembaga zakat yang dibentuk oleh hasil pemikiran masyarakat sipil (Lembaga Amil Zakat).

Seiring berjalannya waktu, terjadi perubahan terhadap regulasi yang berlaku dan dengan digantinya UU No. 38 Tahun 1999 ini dengan UU No. 23 Tahun 2011 yang menyangkut mengenai pengelolaan zakat. UU No. 23 Tahun 2011 berfungsi atas dasar pelaksanaan dan pengelolaan zakat di Indonesia. Peraturan terkait pengelolaan zakat lainnya terdapat pada Peraturan Pemerintah (PP) No. 14 Tahun 2014 dan Instruksi Presiden No. 3 Tahun 2014. PP No. 14 Tahun 2014 mengatur BAZNAS untuk memiliki anggota tertinggi yang ditunjuk secara langsung oleh Presiden. Instruksi Presiden No. 3 Tahun 2014 mewajibkan seluruh 
kementrian, perusahaan BUMN, dan semua lembaga pemerintah untuk membayar dan mengumpulkan zakatnya melalui BAZNAS.

Indonesia merupakan salah satu negara yang kaya akan sumber daya alamnya yang melimpah, menjadikan sebagai salah satu negara agraris. Dengan demikian, maka pembahasan mengenai zakat yang diambil dari hasil pertanian dan perkebunan menjadi sangat signifikan. (Mufrain, 2018)
Salah satu komoditas hasil pertanian (perkebunan) di Indonesia unggulannya adalah kelapa sawit. Produksi minyak sawit dunia didominasi oleh Indonesia dan Malaysia. Kedua negara tersebut secara total menghasilkan sekitar $85-90 \%$ dari total produksi minyak sawit dunia. Menjadikan Indonesia sebagai produsen dan eksportir minyak sawit yang terbesar.

Berdasarkan uraian diatas, dapat dilihat produksi dan ekspor minyak kelapa sawit Indonesia pada tabel berikut:

\section{Tabel 1. Produksi dan Ekspor Minyak Kelapa Sawit Indonesia}

\begin{tabular}{cccc}
\hline Tahun & Produksi (Juta Ton) & $\begin{array}{c}\text { Ekspor (Juta } \\
\text { Ton) }\end{array}$ & $\begin{array}{c}\text { Luas (Juta } \\
\text { Ha) }\end{array}$ \\
\hline 2008 & 19.2 & 15.1 & n.a \\
\hline 2009 & 19.4 & 17.1 & n.a \\
\hline 2010 & 21.8 & 17.1 & n.a \\
\hline 2011 & 23.5 & 17.6 & n.a \\
\hline 2012 & 26.5 & 18.2 & 9.6 \\
\hline 2013 & 30.0 & 22.4 & 10.5 \\
\hline 2014 & 31.5 & 21.7 & 10.7 \\
\hline 2015 & 32.5 & 26.4 & 11.4 \\
\hline 2016 & 32.0 & 27.0 & 11.8 \\
\hline 2017 & 37.9 & 32.1 & 14.0 \\
\hline 2018 & 40.5 & 34.7 & 14.5 \\
\hline 2019 & 42.8 & 37.3 & 14.8
\end{tabular}

Sumber: Indonesia Palm Oil Producers Association (Gapki) dan BPS (2019)

Provinsi Riau adalah produsen minyak sawit terbesar di Indonesia, diikuti Kalimantan Tengah, Sumatera Selatan, dan Kalimantan Barat. Jumlah total luas area perkebunan sawit di Indonesia pada saat ini mencapai sekitar 11,9 juta hektar. Hampir tiga kali lipat dari luas area di tahun 2000 waktu lalu, sekitar 4 juta hektar lahan di Indonesia dipergunakan untuk kelapa sawit. Jumlah ini kemungkinan akan bertambah menjadi 13 juta hektar pada tahun 2020. (Badan Pusat Statistik, 2016)

Berikut ini dapat dilihat tabel produksi kelapa sawit Kabupaten/Kota di Provinsi Riau pada tahun 2019. 
Tabel 2. Produksi Perkebunan Kelapa Sawit Kabupaten/Kota

\begin{tabular}{ccc}
\hline No. & Kabupaten/Kota & $\begin{array}{c}\text { Produksi Perkebunan Kelapa } \\
\text { Sawit, Tahun 2019 }\end{array}$ \\
\hline 1. & Kuantan Singingi & $411,262,00$ \\
\hline 2. & Indragiri Hulu & $423,636,00$ \\
\hline 3. & Indragiri Hilir & $701,544,00$ \\
\hline 4. & Pelalawan & $1,247,072,00$ \\
\hline 5. & Siak & $970,269,00$ \\
\hline 6. & Kampar & $1,217,174,00$ \\
\hline 7. & Rokan Hulu & $1,538,092,00$ \\
\hline 8. & Bengkalis & $414,263,00$ \\
\hline 9. & Rokan Hilir & $807,413,00$ \\
\hline 10. & Kepulauan Meranti & -- \\
\hline 11. & Pekanbaru & $30,834,00$ \\
\hline 12. & Dumai & $80,388,00$ \\
\hline
\end{tabular}

Sumber: Badan Pusat Statistik Provinsi Riau (2019)

Berdasarkan Tabel 2. diatas, Kabupaten Siak merupakan salah satu daerah di Provinsi Riau yang memiliki produksi kelapa sawit yang tidak begitu besar dibandingkan tiga Kabupaten diatasnya, yaitu Kabupaten Rokan Hulu dengan jumlah hasil produksinya mencapai 1,538,092 ton, lalu diurutan kedua Kabupaten Pelalawan dengan hasil produksinya $1,247,072$ ton dan ketiga Kabupaten Kampar dengan hasil produksi 1,217,174 ton tercatat di tahun 2019 terakhir. Tercatat Kabupaten Siak dapat dikatakan hasil produksi kelapa sawitnya cukup besar yaitu dengan total 970,269 ton.

Berdasarkan latar belakang di atas dapat diambil rumusan masalah bagaimana tingkat pengetahuan masyarakat Desa Teluk Merbau Kecamatan Dayun kabupaten Siak terhadap zakat perkebunan kelapa sawit.

\section{TINJAUAN PUSTAKA}

Pengetahuan berasal dari kata tahu, yaitu segala sesuatu yang diketahui. Secara terminology, menurut Sidi Gazalba pengetahuan adalah apa yang diketahui atau hasil dari pekerjaan tahu, pekerjaan tahu tersebut adalah hasil dari kenal, sadar, insaf, mengerti. Pengetahuan merupakan hasil proses dari suatu usaha yang dilakukan manusia untuk tahu. (Amsal, 2014)

Dalam istilah pengetahuan dipergunakan untuk menyebut ketika manusia mengenal sesuatu. Unsur pengetahuan adalah yang mengetahui, diketahui, serta kesadaran tentang hal yang ingin diketahuinya. Oleh karena itu, pengetahuan selalu menuntut adanya subjek yang mempunyai kesadaran untuk mengetahui tentang dan objeknya adalah sesuatu yang dihadapinya sebagai hal yang diketahui. (Soyomukti, 2016)

Menurut Notoadmojo (2010) pengetahuan mengungkapkan bahwa sebelum orang mengadopsi perilaku baru didalam diri orang tersebut terjadi proses sebagai berikut:

1. Kesadaran (Awarenes), dimana orang tersebut menyadari dalam arti mengetahui terlebih dahulu terhadap stimulasi atau objek. 
2. Merasa (Imerest), tertarik terhadap stimulasi atau objek yang dimaksud disini sikap objek mulai timbul.

3. Menimbang-nimbang (Evalution), terhadap baik dan tidaknya stimulasi tersebut bagi dirinya, hal ini berarti sikap responden sudah harus lebih baik lagi.

4. Mencoba (Trail), dimana subjek mulai mencoba melakukan sesuatu sesuai dengan yang dikehendaki.

5. Adaptasi (Adaptation), dimana subjek telah berperilaku baru sesuai dengan pengetahuan kesadaran dan sikap terhadap stimulasi.

Zakat adalah bentuk ibadah yang berfungsi sebagai alat pemerataan pendapatan dalam masyarakat untuk mengurangi kesenjangan antara orang yang berkecukupan dengan orang yang kekurangan. Zakat dapat memperkecil ketimpangan ekonomi masyarakat (Canggih et al, 2017).

Zakat dari segi istilah fiqih berarti "sejumlah harta tertenu yang diwajibkan Allah SWT diberikan atau diserahkan kepada orang-orang yang berhak" di samping berarti "mengeluarkan dengan jumlah tertentu itu sendiri". jumlah yang dikeluarkan dari harta atau kekayaan disebut zakat karena yang dikeluarkan itu akan bertambah banyak, membuat lebih berarti, dan melindungi kekayaan tersebut dari kebinasaan," demikian Nawawi mengutip pendapat Wahidi. (Qardawi, 2011)

Kata zakat dalam bentuk ma'rifah (definisi) disebut tiga puluh kali didalam al-Quran, di antaranya dua puluh tujuh kali disebutkan dalam satu ayat bersama shalat, dan hanya satu kali disebutkan dalam konteks yang sama dengan shalat tetapi tidak didalam satu ayat, yaitu firman-Nya :

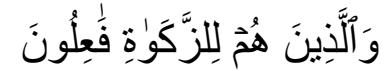

Artinya: "dan orang-orang yang menunaikan zakat, setelah ayat; orang orang yang khusuk dalam sholat". (QS.Al-Mu'minun ayat 4)

Dengan ini zakat diartikan sebagai sesuatu yang suci baik dari, tumbuh, dan berkembang. Walaupun pada zahirnya harta itu berkembang. Akan tetapi pada hakikatnya harta itu akan bertambah, berkembang dan akan membersihkan atau menysucikan harta dan jiwa pemilik harta.

Zakat merupakan dasar prinsipil untuk menegakkan struktur sosial Islam. Zakat bukanlah derma atau sedekah biasa, ia adalah iuran wajib. Ia adalah perintah Allah SWT yang harus dilaksankan menjadikan zakat hukumnya wajib. (Mardani, 2013)

Berdasarkan Undang-Undang Nomor 23 Tahun 2011 Pasal 4, zakat meliputi 2 jenis yaitu zakat fitrah (zakat badan) dan zakat maal (zakat harta). Zakat fitrah merupakan ciri khas umat Islam. Ia disebut zakat fitrah karena diwajibkan atas setiap jiwa atau individu baik untuk orang yang sudah dewasa maupun belum dewasa, yang pelaksanaan pembayaran zakat fitrah tersebut di lakukan saat datang bulan suci Ramadhan atau mendekati hari raya Idhul Fithri. Sedangkan zakat harta ialah zakat yang dikenakan atau harta (maal) yang dimiliki oleh seorang atau lembaga dengan syarat-syarat dan ketentuan yang telah ditetapkan. Maal (harta) menurut bahasa ialah segala sesuatu yang di inginkan sekali oleh manusia untuk menyimpan dan memilikinya, sedangkan maal (harta) menurut hukum Islam adalah segala yang dapat di punyai (di miliki) dan dapat dimanfaatkan atau digunakan menurut kebiasaannya.

Tujuan yang paling utama adalah agar manusia lebih tinggi nilainya daripada harta, sehingga ia menjadi 
tuannya harta bukan menjadi budaknya. Menurut Qardawi (2011) tujuan zakat dan manfaatnya untuk si pemberi adalah sebagai berikut:

a. Zakat mensucikan jiwa dari sifat kikir. Zakat yang dikeluarkan si Muslim semata-mata karena menurut perintah Allah SWT dan mencari ridhonya, akan mensucikan dari berbagai kotoran dosa dan terutama sifat kikir.

b. Zakat mendidik berinfak dan memberi. Sebagai halnya zakat mensucikan jiwa si Muslim dari sifat kikir, ia pun mendidik agar si Muslim rasa ingin berbagi, menyerahkan dan berinfak.

c. Berakhlak dengan akhlak Allah SWT. Manusia apabila sudah suci dari kikir dan batil, dan sudah bisa memberi dan berinfak, akan naiklah ia dari kekotoran sifat kikirnya.

d. Zakat merupakan manifestasi syukur atas nikmat Allah SWT. Sebagaimana dimaklumi, dapat diterima oleh akal fikiran, diakui oleh fitrah manusia, diseru oleh akhlak dan moral serta dianjurkan oleh agama dan syariat, merupakan pengakuan akan keindahan dan bentuk syukur terhadap nikmat itu, merupakan sesuatu keharusan.

e. Zakat mengobati hati dari cinta dunia. Zakat dari segi lain, merupakan suatu peringatan terhadap hati akan kewajibannya kepada Tuhannya dan kepada akhirat serta menjadi obat, untuk hati agar tidak tenggelam terhadap kecintaan akan harta dan kepada dunia secara berlebihan.

f. Zakat mengembangkan kekayaan batin. Diantara tujuan pensucian jiwa yang dibuktikan oleh zakat, adalah tumbuh dan berkembang kekayaan batin dan rasa optimisme. Sesungguhnya orang yang melakukan kebaikan serta menyerahkan yang timbul dari dirinya dan tangannya untuk membangkitkan saudara seagama dan sesama manusia dan menegakkan hak Allah SWT pada orang itu, maka orang tersebut merasa besar, tegar dan luas hatinya.

g. Zakat menarik rasa simpati. Zakat merupakan pengikat antara orang kaya dengan masyarakatnya, dengan ikatan yang kuat, penuh dengan kecintaan, persaudaraan, dan tolong menolong.

h. Zakat mensuciakan harta. Zakat merupakan sebagaimana membersihkan dan mensucikan jiwa juga ia mensucikan dan mengembangkan orang yang memiliki harta. Karena berhubungan atas hak orang lain dengan sesuatu harta, akan menyebabkan harta tersebut bercampur/kotor, yang tidak akan bisa suci kecuali dengan mengeluarkannya.

i. Zakat tidak mensucikan harta yang haram. Apabila kita mengartikan bahwa zakat itu mensucikan harta, dan menjadi sebab bertambah banyaknya dan bertambah berkahnya harta, maka yang dimaksud disini adalah harta yang halal, yang sampai ketangan pemiliknya melalui cara yang dibenarkan agama. Adapun harta yang kotor, yang sampai ketangan pemiliknya melalui rampasan, pencopetan, menyogok atau dengan meninggikan harta, atau melalui riba dan melalui bentukbentuk yang sudah diharamkan dalam syariat Islam. Maka sesungguhnya zakat itu tidak memberikan dampak atau pengaruh apa-apa, tidak mensucikan dan tidak pula berkah.

j. Zakat mengembangkan harta. Zakat, setelah hal-hal yang sudah disebut dan jelaskan diatas, juga 
mengembangkan dan memberkahkan harta.

Syarat zakat adalah segala ketentuan yang wajib dipenuhi oleh seseorang yang akan mengeluarkan hartanya untuk berzakat. Menurut Astuti et al (2018) syarat zakat adalah sebagai berikut:

a. Muslim. Bahwa yang wajib dikenakan zakat adalah orang kaya muslim, sedangkan non muslim tidak dikenakan zakat. Disamping itu zakat adalah salah satu rukun Islam yang hanya diwajibkan bagi orang yang Islam.

b. Merdeka. Menurut Ijma' para ahli fiqih hamba sahanya (budak) tidak dikenakan kewajiban zakat, karenanya secara hukum mereka tidak lagi memiliki harta, karena diri mereka sendiri dianggap menjadi harta.

c. Baligh dan Berakal. Baligh diartikan para fuqaha adalah sudah sampai umur dewasa, artinya sudah paham dan mengerti dengan harta yang ia miliki. Sedangkan berakal, adalah tidak dalam keadaan hilang akal atau ingatan alias gila.

Syarat tersebut dikemukakan oleh ulama Mazhab Hanafi. Oleh sebab itu anak kecil atau orang gila yang memliki harta mencapai satu nishab, tidak dikenai kewajiban zakat, karena mereka tidak dituntut untuk beribadah, seperti shalat dan berpuasa.

Syarat harta kekayaan yang wajib dikeluarkan zakatnya ialah (Azzam dan Hawwas, 2013) :

a. Milik sempurna. Yang dimaksud milik sempurna adalah bahwa kekayaan itu harus berada dibawah kontrol dan di dalam kekausaannya. Dengan arti lain, harta kekayaan itu harus ada ditangannya, tidak ada di dalamnya hak orang lain, dapat ia pergunakan dan faedahnya dapat dinikmati. b. Cukup nishab. Nishab adalah kadar atau ukuran minimal harta kekayaan diwajibkan dikeluarkan zakatnya. Apabila harta itu telah mencapai jumlah minimal yang wajib dikeluarkan zakat nya maka harta kekayaan harus dikeluarkan zakatnya, dan sebaliknya jika harta seorang muslim belum sampai nishab maka ia tidak wajib mengeluarkan zakatnya.

c. Berlalu setahun. Maksudnya adalah bahwa pemilikan yang berada di tangan si pemilik sudah berlalu masanya dua belas bulan Qomariyah. Tetapi Persyaratan setahun itu hanya untuk barang yang dimaksud kedalam istilah "zakat modal" contohnya seperti: ternak, uang, barang yang diperdagangkan, dll. Dan adapun hasil dari bumi, logam mulia harta karun, madu, dan lain-lain yang sejenis itu termasuk dalam istilah "zakat pendapatan" tidak dipersyaratkan satu tahun (dikeluarkan ketika diperoleh).

d. Lebih dari kebutuhan biasa atau kebutuhan pokok. Harta yang dipunyai oleh sesorang itu melebihi kebutuhan pokok atau kebutuhan rutin oleh dirinya sendiri maupun untuk keluarganya dengan catatan hidup secara wajar sebagai manusia.

e. Berkembang. Secara pengertian berkembang adalah sifat dari harta kekayaan itu membawa baik secara keuntungan maupun pendapatan. Harta yang senantiasa bertambah baik secara konkrit adalah bertambah akibat dikembangkan dengan sengaja. Berkembang tidak secara kongkrit adalah kekayaan yang mempunyai potensi berkembang baik dikembang kan oleh si pemilik harta maupun ditangan orang lain tetapi harta tersebut masih atas kepemilikannya.

f. Bebas dari hutang. Artinya harta kekayaan yang dimilikinya itu melebihi kebutuhan primer atau kebutuhan 
pokok diatas harus pula cukup satu nisab yang sudah bebas dari hutang, baik hutang kepada Allah SWT (nazar, wasiat) maupun hutang kepada sesama manusia.

g. Harta yang halal. Dipersyaratkan kepemilikan atas harta kekayaan milik sebagai wajib zakat membuat kekayaan yang diperoleh dengan cara yang tidak baik atau tidak dibenarkan atau haram tidak termasuk ke dalam wajib zakat, contohnya: perampasan, pencurian, penipuan, riba, spekulasi, dan lainlainya dengan cara mengambil harta kekayaan orang lain dengan cara yang tidak dibenarkan.

Hasil pertanian adalah hasil tumbuh-tumbuhan atau tanaman yang dikeluarkan oleh Allah SWT dari bumi untuk dikelola dimanfaatkan oleh manusia yang bernilai ekonomi seperti buahbuahan, biji-bijian, umbi, sayur dan lain sebagainya. (Soemitra, 2010)

Zakat pertanian dalam bahasa arab sering disebut dengan istilah az-zuru' wa ats-tsimar (tanaman dan buah-buahan) atau at-nabit au al-kharij min al-ardh (yang tumbuh dan keluar dari bumi), yaitu zakat hasil bumi yang berupa biji-bijian, sayur-sayuran dan buah-buahan sesuai dengan yang ditetapkan dalam Al-Qur'an dan Sunah dan Ijma' Ulama.

Secara umum dinyatakan dalam $\mathrm{Al}$ Qur'an, bahwa rezeki apa pun yang kita dapat dari Allah SWT, agar diinfaqkan sebagiannya, sebagai mana firman Allah SWT :

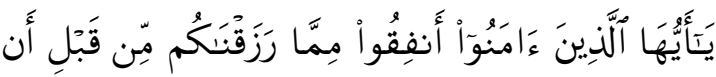

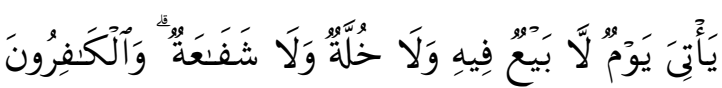

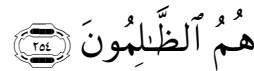

Artinya: "Hai orang-orang yang beriman, belanjakanlah (di jalan Allah) sebagian dari rezki yang telah Kami berikan kepadamu sebelum datang hari yang pada hari itu tidak ada lagi jual beli dan tidak ada lagi syafa'at. dan orang-orang kafir Itulah orang-orang yang zalim”.'( Q.S. Al-Baqarah ayat 254)

Dari ayat diatas dapat dipahami bahwa apa pun hasil pertanian, baik tanaman keras maupun tanaman lunak (muda), wajib dikeluarkan zakatnya, kalau sudah sampai nishab pada waktu memetik hasilnya. Didalam zakat pertanian ini, tidak seorangpun dari ulama yang menyangkal wajibnya zakat pada tanaman dan buahbuahan. Akan tetapi, perdebatan yang ada diantara para fuqaha adalah pada jenisjenis yang diwajibkan, mengenai ini terdapat beberapa pendapat para ulama, antara lain:

Al-Hasan al-Basri, al-Tsauri dan as-Sya'bi berpendapat bahwa hanya empat macam saja jenis tanaman yang wajib dizakati, yaitu biji gandum, padi, kurma dan kurma dan anggur, Syaukani juga berpendapat demikian. Alasan kelompok ini adalah, karena hanya itulah yang disebutkan didalam nash (hadist). $\quad$ Abu Hanifah berpendapat, bahwa semua tanaman yang diusahakan (diproduksi) oleh manusia dikenakan zakat, kecuali pohon-pohonan yang tidak berbuah. Abu Yusuf dan Muhammad (keduanya murid Abu Hanafiah) berpendapat, bahwa semua tanaman yang bisa bertahan selama satu tahun (tanpa bahan pengawet), dikenakan zakat. Malik berpendapat, bahwa tanaman yang bisa tahan lama, kering dan diproduksi atau diusahakan oleh manusia dikenakan zakat. Syafi'i berpendapat, bahwa semua tanaman yang mengenyangkan (memberi kekuatan), bisa disimpan (padi, jagung) dan diolah manusia, wajib dikeluarkan zakatnya. Ahmad bin Hambali berpendapat, bahwa semua hasil tanaman yang kering, tahan lama, dapat ditimbang (takar) dan diproduksi (diolah) oleh manusia dikenakan zakat. Mahmud Syaltut berpendapat bahwa semua hasil tanaman 
dan buah-buahan yang dihasilkan oleh manusia dikenakan zakat.

Hasil pertanian tersebut ditanaman oleh manusia. Jika hasil pertanian tersebut tumbuh dengan sendirinya tanpa campur tangan manusia melainkan dengan perantara air atau udara maka tidak wajib dizakati. Oleh karena itu, tidak ada kewajiban mengeluarkan zakatnya pada sesuatu yang tumbuh dan berkembang dengan sendirinya. Menurut pendapat yang shahih, hasil-hasil tanaman tidak wajib dikeluarkan zakatnya karena tidak memiliki pemilik definitif atau pemilik sahnya. Seandainya ada yang memilikinya secara definitife, dalam artinya ia memang tumbuh ditanah wakaf namun ditanam oleh seseorang benihnya berasal dari si penanam tersebut maka hasilnya wajib dikeluarkan zakatnya (jika memang memenuhi syarat yang lain).

Hasil pertanian tersebut merupakan jenis makanan pokok manusia yang dapat disimpan dan jika disimpan tidak rusak. Sudah mencapai nishab. Dalam penjelasan ini, nisab atau ukuran masing-masing jenis hasil bumi atau hasil pertanian dihitung sendiri-sendiri, bukan gabungan dari jenis yang satu dengan yang lainnya. Adapun nishab zakat hasil pertanian adalah 5 wasq (1 wasq $=60$ sha') Rasulullah SAW bersabda:

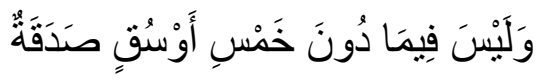

Artinya: "Tidak ada zakat pada (hasil pertanian) dibawah lima wasq."

Tidak seperti emas dan perak, zakat hasil pertanian tidak mensyaratkan terpenuhinya satu tahun (haul), akan tetapi zakat diwajibkan ketika hasil pertanian dan buah-buahan sudah tampak matang dan siap panen, baik sebagian maupun seluruhnya.

Hasil pertanian tidak wajib dikeluarkan zakatnya sebelum mencapai nishab, yaitu 5 wasq, 1 wasq adalah 60 sha', sedangkan 1 sha' sama dengan 2,2 kg. Jadi, 1 wasq kurang lebih sama dengan $132,6 \mathrm{~kg}$. Kadar nishab hasil pertanian adalah $5 \mathrm{wasq} \times 132,6 \mathrm{~kg}=663$ $\mathrm{kg}$. Inilah ketentuan nishab wajib zakat hasil pertanian. kadar nishab ini sebenarnya tidak banyak mengurangi hasil panen. Dengan demikian jelaslah bahwa harta yang kurang dari ukuran nishab tersebut tidak wajib zakat.

Berdasarkan uraian diatas mengenai zakat, berikut ini adalah pedoman perhitungan zakat yang diterapkan BAZNAS Kabupaten Siak:

Tabel 3: Cara Penghitungan Zakat Pada BAZNAS Kabupaten Siak

\begin{tabular}{|c|c|c|c|c|c|c|}
\hline No & $\begin{array}{c}\text { Jenis } \\
\text { Harta }\end{array}$ & Nisab & Haul & $\begin{array}{c}\text { Persent } \\
\text { ase }\end{array}$ & Contoh Kasus & Keterangan \\
\hline 1 & Emas & 85 gram & $\begin{array}{l}1 \\
\text { Tahun }\end{array}$ & $2,5 \%$ & $\begin{array}{l}\text { Bu Rani memiliki emas } 120 \\
\text { gr, maka zakatnya, } 120 \text { gr } \times \\
400.000 .000 \text { per gram }= \\
48.000 .000 \times 2,5 \%=\text { Rp. } \\
1.200 .00\end{array}$ & $\begin{array}{l}85 \text { gram emas } \\
\text { setara dengan } \\
\text { Rp.34.000.000 }\end{array}$ \\
\hline 2 & Perak & 595 gram & $\begin{array}{l}1 \\
\text { Tahun }\end{array}$ & $2,5 \%$ & $\begin{array}{l}\text { Rubi memiliki perak } 700 \text { gr, } \\
\text { maka zakatnya, } 700 \text { gr } \times \\
200.000 \text { per gram }= \\
140.000 .000 \times 2,5 \%=\text { Rp. } \\
3.500 .000\end{array}$ & \\
\hline
\end{tabular}




\begin{tabular}{|c|c|c|c|c|c|c|}
\hline 3 & $\begin{array}{l}\text { Uang } \\
\text { Simpan } \\
\text { an }\end{array}$ & 85 gram & $\begin{array}{l}1 \\
\text { Tahun }\end{array}$ & $2,5 \%$ & $\begin{array}{l}\text { Pak Andre mempunyai uang } \\
\text { di bank Rp. } 40.000 .000 \text {, dan } \\
\text { sudah berjalan selama } 1 \\
\text { tahun, maka zakatnya adalah } \\
40.000 .000 \times 2,5 \%=\mathrm{Rp} . \\
1.000 .000\end{array}$ & $\begin{array}{l}\text { Nilai simpan } \\
\text { harus mencapai } \\
\text { Rp. 34.000.000 }\end{array}$ \\
\hline 4 & $\begin{array}{l}\text { Harta } \\
\text { Dagang }\end{array}$ & $\begin{array}{ll}85 & \text { gram } \\
\text { emas } & \end{array}$ & $\begin{array}{l}1 \\
\text { Tahun }\end{array}$ & $2,5 \%$ & $\begin{array}{l}\text { Pak Burhan memiliki usaha } \\
\text { percetakan, barang yang ada } \\
\text { ditokonya bernilai Rp. } \\
100.000 .000 \text { ditambah } \\
\text { keuntungan pada saat jatuh } \\
\text { tempo zakat sebesar Rp. } \\
50.000 .000 \text {, ditambah dengan } \\
\text { piutang Rp. 30.000.000, } \\
\text { Total nilai keseluruhan Rp. } \\
180.000 .000 \times 2,5 \%= \\
4.500 .000\end{array}$ & $\begin{array}{l}\text { Boleh dikurangi } \\
\text { hutang, tetapi } \\
\text { hutang } \\
\text { perniagaan yang } \\
\text { terjadi pada saat } \\
\text { jatuh tempo } \\
\text { bayar zakat }\end{array}$ \\
\hline 5 & $\begin{array}{l}\text { Perusah } \\
\text { aan }\end{array}$ & 85 gram & $\begin{array}{l}1 \\
\text { Tahun }\end{array}$ & $2,5 \%$ & $\begin{array}{l}\text { Laba bersih CV milik Pak } \\
\text { Ahmad Rp. } 76.000 .000 \text { pada } \\
\text { akhir tahun, maka zakatnya } \\
76.000 .000 \times 2,5 \%=\text { Rp. } \\
1.900 .000\end{array}$ & $\begin{array}{l}\text { Maksudnya laba } \\
\text { bersih adalah } \\
\text { setelah } \\
\text { pengurangan } \\
\text { biaya } \\
\text { operasional } \\
\text { perusahaan }\end{array}$ \\
\hline \multirow[t]{2}{*}{6} & $\begin{array}{l}\text { Pertani } \\
\text { an }\end{array}$ & $\begin{array}{l}653 \quad \mathrm{Kg} \\
\text { gabah atau } \\
\text { setara } \\
\text { dengan } \\
520 \quad \mathrm{Kg} \\
\text { beras }\end{array}$ & $\begin{array}{l}\text { Setiap } \\
\text { Panen }\end{array}$ & $5 \%$ & $\begin{array}{l}\text { Pak Samparis memanen padi } \\
\text { sebanyak } 730 \mathrm{~kg} \times 5 \%=3,6 \\
\mathrm{~kg} \text { (boleh diuangkan dengan } \\
\text { harga perkilogramnya) }\end{array}$ & $\begin{array}{l}\text { Jika } \\
\text { Pengolahannya } \\
\text { memerlukan } \\
\text { biaya } \\
\text { operasional } \\
\text { seperti pupuk, } \\
\text { dll. }\end{array}$ \\
\hline & & & & $10 \%$ & $\begin{array}{l}\text { Pak Ovi memanen padi } \\
\text { sebanyak } 730 \mathrm{~kg}, \quad \text { maka } \\
\text { zakat yang dikeluarkan } 730 \\
\mathrm{~kg} \times 10 \%=73 \mathrm{~kg} \text { (boleh } \\
\text { diuangkan dengan harga } \\
\text { perkilogramnya) }\end{array}$ & $\begin{array}{l}\text { Jika } \\
\text { pengolahannya } \\
\text { tidak } \\
\text { memerlukan } \\
\text { biaya } \\
\text { operasioanal } \\
\text { seperti pupuk } \\
\text { dll. }\end{array}$ \\
\hline 7 & Profesi & $\begin{array}{ll}85 & \text { gram } \\
\text { emas } & \end{array}$ & $\begin{array}{l}1 \\
\text { Tahun }\end{array}$ & $2,5 \%$ & $\begin{array}{l}\text { Nanang berprofesi sebagai } \\
\text { kepala sekolah, ia } \\
\text { mendapatkan penghasilan } \\
\text { setiap bulannya yang terdiri } \\
\text { dari gaji Rp. } 3.000 .000 \\
\text { tunjangan profesi Rp. } \\
2.000 .000 \text { penghasilan lainya } \\
\text { Rp. } 1.000 .000 \text { maka zakat } \\
\text { yang harus dibayar adalah } \\
\text { Rp. } 6.000 .000 \times 2,5 \%=\mathrm{Rp} \text {. } \\
150.000 \text { perbulannya }\end{array}$ & $\begin{array}{l}\text { Pengeluaran } \\
\text { zakat dapat } \\
\text { dilakukan } \\
\text { perbulan atau } \\
\text { sebelum sampai } \\
\text { haul mengingat } \\
\text { hadist Rasulullah } \\
\text { SAW. }\end{array}$ \\
\hline 8 & $\begin{array}{l}\text { Perkeb } \\
\text { unan }\end{array}$ & $\begin{array}{ll}85 & \text { gram } \\
\text { emas } & \end{array}$ & 1 tahun & $2,5 \%$ & $\begin{array}{l}\text { Perkiraan hasil panen sawit } \\
\text { Pak Fadhli mencapai Rp. } \\
34.000 .000 \text { atau lebih dalam } \\
1 \text { tahun maka setiap kali } \\
\text { panen dikeluarkan zakatnya }\end{array}$ & $\begin{array}{l}\text { Hasil panen } \\
\text { sawit dizakatkan } \\
\text { setelah dikurangi } \\
\text { biaya } \\
\text { operasional }\end{array}$ \\
\hline
\end{tabular}




\begin{tabular}{llll}
\hline & & sebesar 2,5\% & $\begin{array}{c}\text { sawit seperti } \\
\text { pupuk dan upah } \\
\text { buruh (netto) }\end{array}$ \\
\hline $9 \quad$ Fitrah & Kelebihan & $2,5 \mathrm{~kg}$ & \\
& dari & beras & \\
& makanan & yang \\
& pokok dimakan & \\
& pada saat & sehari- & \\
& hari raya & hari & \\
& tanggal 1 & & \\
& syawal & & \\
\hline
\end{tabular}

\section{METODE PENELITIAN}

Penelitian ini menggunakan jenis penelitian lapangan (Field Research), yaitu penelitian yang langsung dilakukan dilapangan atau kepada responden. (Misbahuddin dan Hasan, 2014)

Jenis penelitian yang digunakan yaitu penelitian deskriptif merupakan jenis penelitian yang disusun dalam rangka memberikan gambaran secara sistematis tentang informasi ilmiah yang berasal dari subjek atau objek penelitian. (Sanusi, 2017)

Penelitian ini dilaksanakan di Desa Teluk Merbau. Waktu yang diperlukan untuk Penelitian ini selama 4 (Empat) bulan, terhitung dari bulan Mei sampai bulan Agustus tahun 2020.

Adapun yang menjadi subjek penelitian ini adalah masyarakat Desa Teluk Merbau yang menetap dan berdomisili diwilayah Desa Teluk Merbau. Sedangkan yang menjadi objek penelitian ini adalah tingkat pengetahuan masyarakat Desa Teluk Merbau tentang zakat hasil perkebunan kelapa sawit.

Populasi adalah seluruh kumpulan elemen yang menunjukan ciri-ciri tertentu yang dapat digunakan untuk membuat kesimpulan. (Sanusi, 2017). Populasi dalam penelitian ini adalah masyarakat Desa Teluk Merbau tahun 2019 yang berjumlah 518 Kepala Keluarga. (Pemerintah Desa Teluk Merbau).

Dalam menentukan ukuran sampel penelitian, Slovin memasukan unsur kelonggaran ketidak telitian karena kesalahan pengambilan sampel yang masih dapat ditoleransi. Karena banyaknya jumlah populasi secara keseluruhan dari masyarakat Desa Teluk Merbau tersebut. (Sanusi, 2017) Berikut adalah daftar tabel ukuran sampel menurut dusun di Desa Teluk Merbau:

Berikut adalah daftar tabel ukuran sampel menurut dusun di Desa Teluk Merbau:

Tabel 10. Ukuran Sampel Menurut Dusun di Desa Teluk Merbau

\begin{tabular}{llcc}
\hline & \multicolumn{1}{c}{ Dusun } & Jumlah & Sampel \\
\hline 1 & Becah Terentang & 176 & 29 \\
\hline 2 & Bumi Rejo & 185 & 30 \\
\hline 3 & Demak Kuantan & 157 & 25 \\
\hline & Jumlah & $\mathbf{5 1 8}$ & $\mathbf{8 4}$ \\
\hline
\end{tabular}


Sampel tersebut kemudian ditentukan jumlah masing-masing sampel menurut tingkat (strata) dengan teknik pengambilan sampel menggunakan Proportionate Stratified Random Sampling, yaitu pengambilan sampel dari anggota populasi dan berstrata secara proposional, dengan rumus (Riduwan, 2014):

$\mathrm{ni}=\mathrm{Ni} / \mathrm{N} . \mathrm{n}$

a. Becah Terentang :

$176 / 518 \times 84=28,54=29$ responden

b. Bumi Rejo :

$185 / 518 \times 84=30=30$ responden

c. Demak Kuantan :

$157 / 518 \times 84=25,45=25$ responden

Keterangan :

ni $\quad=$ jumlah sampel menurut stratum.

$\mathrm{n} \quad=$ jumlah sampel seluruhnya.

$\mathrm{Ni}=$ jumlah populasi menurut stratum.

$\mathrm{N} \quad=$ jumlah populasi seluruhnya

Dalam penelitian ini penulis mendapatkan data-data kongkrit yaitu data primer dan data sekunder yang benarbenar bisa mendukung dalam mengumpulkan data, beberapa teknik diantaranya adalah kuesioner membuat sejumlah pertanyaan tertulis yang diajukan terhadap responden yang dianggap sampel yang terpilih.

Sumber data yang digunakan dalam penelitian ini terbagi menjadi dua bagian, yaitu sebagai berikut : a. Data Primer adalah data yang diperoleh atau dikumpulkan dan diolah sendiri oleh suatu organisasi atau perorangan langsung dari sumber aslinya. Dalam penelitian ini, maka proses pengumpulan datanya dilakukan dengan memperhatikan siapa sumber utama yang akan di jadikan objek penlelitian, yaitu memakai angket atau kosioner yang di isi oleh responden. b.
Data Sekunder adalah sumber data yang diperoleh secara tidak langsung dan dalam bentuk yang sudah jadi. Data ini diperoleh dari literatur-literatur yang berkaitan dengan judul yang penulis akan melaukuan penelitian. Itu biasanya berupa jurnal, buku-buku yang berkaitan dan penelitian terdahulu yang relevan dengan judul peneliti.

Metode yang dipakai dalam penelitian ini menggunakan skala Guttman yang merupakan suatu skala kumulatif, skala yang dipakai untuk jawaban yang bersifat jelas dan konsisiten seperti hal nya jawaban benar-salah. Skala Guttman dapat dibuat dalam bentuk pilihan ganda dan bisa juga dibuat dalam bentuk checklist atau silang. Jawaban responden dapat berupa skor tertinggi bernilai (1) dan skor rendah (0) (Riduwan, 2014).

$$
\text { Benar }=1 \quad \text { Salah }=0
$$

\section{HASIL DAN PEMBAHASAN}

\section{Tinjauan Umum Lokasi Penelitian}

Desa Teluk Merbau merupakan Desa Exs UPT VII Buatan II PIR ADB PTPN II Nusantara V yang sekarang berubah menjadi PTPN V yang penempatannya sejak tahun 1989. Dahulu Desa Teluk Merbau menginduk ke Desa Dayun Kecamatan Siak Kabupaten Bengkalis. Sejak tahun 1997 Desa Teluk Merbau menjadi Desa definitif yang menginduk ke Desa Dayun Kecamatan Siak Kabupaten Bengkalis. Berdasarkan Undang-Undang No.53 tahun 1999 tentang pemekaran wilayah, maka Desa Teluk Merbau masuk wilayah Kecamatan Dayun Kabupaten Siak pada tahun 1999.

\section{Analisis Data}

Penelitian ini merupakan penelitian deskriptif. Penelitian deskriptif adalah penelitian yang disusun dalam rangka memberikan gambaran secara sistematis tentang informasi ilmiah yang 
berasal dari subjek dan objek penelitian (Sanusi, 2017).

Berikut hasil rekapitulasi dari 35 butir pertanyaan melalui angket kepada

Tabel 4. Rekapitulasi Hasil Angket Tentang Analisis Tingkat Pengetahuan Masyarakat Terhadap Zakat Perkebunan Kelapa Sawit Di Desa Teluk Merbau Kecamatan Dayun Kabupaten Siak.

\begin{tabular}{|c|c|c|c|c|c|}
\hline \multirow{3}{*}{ No } & \multicolumn{4}{|c|}{ Frekuensi } & \multirow{3}{*}{ Skor } \\
\hline & Benar & \multirow[t]{2}{*}{$\%$} & Salah & \multirow[t]{2}{*}{$\%$} & \\
\hline & 1 & & 0 & & \\
\hline 1 & 84 & 100 & 0 & 0 & 84 \\
\hline 2 & 74 & 88,1 & 10 & 11,9 & 74 \\
\hline 3 & 72 & 85,7 & 12 & 14,3 & 72 \\
\hline 4 & 57 & 67,9 & 27 & 32,1 & 57 \\
\hline 5 & 57 & 67,9 & 27 & 32,1 & 57 \\
\hline 6 & 67 & 79,8 & 17 & 20,2 & 67 \\
\hline 7 & 69 & 82,1 & 15 & 17,9 & 69 \\
\hline 8 & 78 & 92,9 & 6 & 7,1 & 78 \\
\hline 9 & 75 & 89,3 & 9 & 10,7 & 75 \\
\hline 10 & 53 & 63,1 & 31 & 36,9 & 53 \\
\hline 11 & 40 & 47,6 & 44 & 52,4 & 40 \\
\hline 12 & 40 & 47,6 & 44 & 52,4 & 40 \\
\hline 13 & 80 & 95,2 & 4 & 4,8 & 80 \\
\hline 14 & 79 & 94,0 & 5 & 6,0 & 79 \\
\hline 15 & 58 & 69,0 & 26 & 31,0 & 58 \\
\hline 16 & 51 & 60,7 & 33 & 39,3 & 51 \\
\hline 17 & 82 & 97,6 & 2 & 2,4 & 82 \\
\hline 18 & 23 & 27,4 & 61 & 72,6 & 23 \\
\hline 19 & 37 & 44,0 & 47 & 56,0 & 37 \\
\hline 20 & 38 & 45,2 & 46 & 54,8 & 38 \\
\hline 21 & 27 & 32,1 & 57 & 67,9 & 27 \\
\hline 22 & 55 & 65,1 & 29 & 34,5 & 55 \\
\hline 23 & 40 & 47,6 & 44 & 52,3 & 40 \\
\hline 24 & 38 & 45,2 & 46 & 53,6 & 38 \\
\hline 25 & 38 & 45,2 & 46 & 54,8 & 38 \\
\hline 26 & 40 & 47,6 & 44 & 52,4 & 40 \\
\hline 27 & 47 & 56,0 & 37 & 44,0 & 47 \\
\hline 28 & 53 & 63,1 & 31 & 36,9 & 53 \\
\hline
\end{tabular}


2021, Jurnal Tabarru' : Islamic Banking and Finance 4 (1) : 84 - 98

\begin{tabular}{llllll}
\hline 29 & 42 & 50,0 & 42 & 50,0 & 42 \\
\hline 30 & 81 & 96,4 & 3 & 3,6 & 81 \\
\hline 31 & 53 & 63,1 & 31 & 36,9 & 53 \\
\hline 32 & 66 & 78,6 & 18 & 21,4 & 66 \\
\hline 33 & 80 & 95,2 & 4 & 4,8 & 80 \\
\hline 34 & 54 & 64,3 & 30 & 35,7 & 54 \\
\hline 35 & 33 & 39,3 & 51 & 60,7 & 33 \\
\hline & Total Skor Responden & & $\mathbf{1 . 9 6 1}$ \\
\hline
\end{tabular}

Sumber: Data Olahan (2020)

Penelitian ini tentang bagaimana tingkat pengetahuan masyarakat Desa Teluk Merbau terhadap zakat perkebunan kelapa sawit menggunakan satu variabel.

Berdasarkan tabulasi data diatas dapat di interprestasikan berdasarkan skor untuk mengetahui tingkat pengetahuan masyarakat Desa Teluk Merbau terhadap zakat, jika skor, jika skor berada pada rentang nilai 61\%-80\%: 5) Sangat kuat, jika skor berada berada pada rentang nilai 20\%-40\%: 3) Cukup atau cukup mengetahui, jika skor berada pada rentang nilai 41\%-60\%: 4) Kuat atau perkebunan kelapa sawit. Kriteria skor yaitu: 1) Sangat Lemah atau sangat tidak mengetahui, jika skor berada pada rentang nilai 0-20\%: 2) Lemah atau tidak mengetahui mengetahui pada rentang nilai $81 \%-100 \%$.

Dari tabel di atas dapat diketahui bahwa skor yang diperoleh dari responden adalah 1.961, sedangkan skor ideal (skor tertinggi) yaitu $35 \times 1 \times 84=2.940$ dari data di atas dapat diketahui bahwa tingkat pengetahuan masyarakat Desa Teluk Merbau terhadap zakat perkebunan kelapa sawit adalah tergolong kuat atau mengetahui $(1.961 / 2.940 \times 100 \%=$ $66,70 \%)$.

Berdasarkan hasil dari analisis statistik yang telah penulis lakukan dalam penelitian ini, diketahui bahwa pengetahuan masyarakat Desa Teluk Merbau terhadap zakat perkebunan kelapa sawit adalah "kuat atau mengetahui" dengan persentase $66,70 \%$.

Pada angket, untuk melihat berada di tingkatan mana pengetahuan masyarakat berdasarkan teori dari tingkatan pengetahuan Tahu (Know), memahami (Comprehension), Aplikasi (Aplikasi), Analisis (Analysis), Sintesis (Synthesis), dan Evaluasi (Evaluation) dilihat dari hasil rekapitulasi skor jawaban responden skor jawaban responden nilai tertinggi terletak pada Tahu (Know) dengan jumlah respon yaitu 84 atau $100 \%$ masyarakat menjawab tahu untuk pertanyaan apakah mengetahui membayar zakat sebagai kewajiban yang wajib dilaksanakan bagi seorang muslim, sedangkan untuk tingkat memahami jawaban paling tinggi terletak pada point faham terhadap pertanyaan memahami perbedaan antara zakat, infaq, dan sedekah dengan perolehan skor 80 atau 95,2\%. Untuk aplikasinya, rata-rata masyarakat masih tidak sesuai membayarkan zakat dengan zakat yang dihadapkan untuk seorang petani yaitu zakat perkebunan kelapa sawit.

Oleh karena itu sangat diperlukan sosialisasi secara langsung kepada masyarakat apa itu zakat perkebunan kelapa sawit dan ketentuan-ketentuannya. Ketika peneliti menyebar angket, beberapa masyarakat pun ingin adanya sosialisasi langsung kepada mereka pemilik kebun kelapa sawit, karena bukan tidak mau mengeluarkan zakat dari 
perkebunan sawit mereka, melainkan masih menjadi suatu hal yang tabu atau belum jelas apa itu zakat perkebunan dan yang mencakup berbagai hal di dalamnya.

Dengan begitu, jika pengetahuan dan pemahaman masyarakat terhadap zakat perkebunan kelapa sawit baik dan meningkat, maka tingkat kesadaran dan pengumpulan zakat pun akan meningkat.

\section{KESIMPULAN}

Dari hasil analisis data dan interprestasi skor, diketahui pengetahuan masyarakat Desa Teluk Merbau terhadap zakat perkebunan kelapa sawit tergolong "kuat atau mengetahui". Akan tetapi jika dilihat dari teori tingkatan pengetahuan sebagaimana yang telah dijabarkan di dalam angket yang terbagi atas tahu, memahami, aplikasi, analisis, sintesis, dan evaluasi, dalam prakteknya masyarakat masih belum merealisasikan dalam menunaikan zakat perkebunan karena masih banyak petani belum mengeluarkan zakat perkebunannya.

\section{DAFTAR PUSTAKA}

Astuti, Daharmi., Rusby, Zulkifli., \& Zulbaidi. 2018. Manajemen Pengelolaan Zakat di UPZ Instansi Pemerintah Provinsi Riau. AlHikmah : Jurnal Agama dan Ilmu Pengetahuan, 15(1), 1412-5382.

Astuti, Daharmi., Rusby, Zulkifli., \& Zulbaidi. 2017. Implementasi Zakat Profesi di UPZ Pemerintah Provinsi Riau. Al-Hikmah : Jurnal Agama dan Ilmu Pengetahuan, 14(1), 14125382.

Azzam, Abdul Aziz Muhammad dan Hawwas, Abdul Wahab Sayyed. 2013. Fiqih Ibadah, (Penerjemah: Kamran As'at Irsyady). Amzah. Jakarta.
Badan Pusat Statistik Republik Indonesia. 2016. Data Letak Geografis Provinsi Riau.

Bakhtiar, Amsal. 2010. Filsafat Ilmu, Rajawali Pers. Jakarta.

Canggih, Clarashinta., Fikriyah, Khusnul., \& Ach Yasin. 2017. Inklusi Pembayaran Zakat di Indonesia, Jurnal Ekonomi dan Bisnis Islam, 3 (1), 1-11.

H. Rasjid, Sulaiman. 2014. Fiqih Islam. Sinar Baru Algensindo. Bandung.

Mardani. 2013. Fiqih Ekonomi Syariah: Fiqih Muamalah. Kencana Prenadamedia Group. Jakarta.

Misbahudin dan Hasan, Iqbal. 2014. Analisis Data Penelitian Dengan Statistik. Bumi Aksara. Jakarta.

Mufrain, Arif. 2018. Akutansi Dan Manajemen Zakat. Prenamedia Group. Jakarta.

Notoatmodjo, Soekidjo. 2010. Pengantar Pendidikan Kesehatan dan Ilmu Perilaku Kesehatan. Andi Offset. Yogyakarta.

Qardawi, Yusuf. 2011. Hukum Zakat, Litera Antar Nusa. Jakarta.

Riduwan. 2014. Dasar-dasar statistik. Alfabeta. Bandung.

Sanusi, Anwar. 2017. Metodologi Penelitian Bisnis. Salemba Empat. Jakarta.

Soemitra, Andri. 2010. Bank Dan Lembaga Keuangan Syariah. Kencana Prenada Media Group. Jakarta.

Soyomukti, Nurani. 2016. Pengantar Filsafat Umum. Ar-Ruzz Media. Jogjakarta. 